\title{
ANALISIS KUALITAS PRODUK KERAJINAN LIMBAH KAYU TERHADAP KEPUASAN PELANGGAN DENGAN PENDEKATAN CUSTOMER SATIFACTION INDEX DAN KANO MODEL Studi Kasus UMKM Succes Creative Desa Donorejo
}

\author{
Muhammad Nasta'in, Widya Setiafindari \\ Program Studi Teknik Industri Fakultas Sains dan Teknologi Universitas Teknologi \\ Yogyakarta \\ mnastain26@gmail.com, widyasetia@uty.ac.id
}

\begin{abstract}
This study was carried out to analyze customer satisfaction level toward the product since complaints were frequently found after purchasing the products. This study applied Customer Satifaction Index method and Kani Model to analyze comprehensively customer satisfaction level by observing attribute importances of a product and then categorizing them based on their capability to give satisfaction to the customers of UMKM Success Creative. This method was carried out to investigate the customer satisfation level and offer quality betterment suggestion to the product characteristics. The result of Customer Satisfaction methode showed the percentage of customer satisfaction i.e $75.36 \%$. For it was between range $71 \%<X \leq 77 \%$, the product quality was considered couse for concern meaning the products were required for the quality betterment to reach customer satisfaction. The Kano Model calculation revealed the cutomer satisfaction rate was 0.393 which was smaller than the dissatisfaction rate i.e 0.405 . Therefore, betterment for quality product was required to fulfill the customer satisfaction.
\end{abstract}

Keywords: product, quality, Customer, Satifaction, Index

\begin{abstract}
Abstrak
Penelitian pada UMKM Succes Creative ini dilakukan untuk menganalisis tingkat kepuasan pelanggan terhadap produk yang dihasilkan, penelitian ini dilakukan karena sering terdapat keluhan pelanggan terhadap produk yang telah dibelinya contohnya pada bulan desember 2019 terdapat 18 keluhan pelanggan. Penelitian ini menggunakan metode Customer Satifaction Index dan Kano Model yang merupakan metode digunakan untuk menganalisis tingkat kepuasan pelanggan secara menyeluruh dengan melihat kepentingan atribut-atribut dari suatu produk, kemudian mengkategorikan atribut-atribut tersebut berdasarkan seberapa baik suatu produk mampu memuaskan kebutuhan pelanggan UMKM Succes Creative. Penggunaan metode ini bertujuan untuk mengetahui tingkat kepuasan konsumen dan memberi usulan perbaikan kualitas dari karakteristik produk yang dihasilkan UMKM Succes Creative. Hasil perhitungan menggunakan metode Customer Satisfaction didapatkan nilai prosentase kepuasan pembeli sebesar $75,36 \%$. Hasil perhitungan tersebut terdapat diantara range $71 \%<\mathrm{X} \leq 77 \%$, karena hasil perhitungan diantra range tersebut maka kualitas produk dikatakan couse for concern sehingga produk yang dihasilkan perlu dilakukan perbaikan untuk memenuhi kepuasan konsumen atau pembeli. Dari perhitungan Kano Model didapatkan angka kepuasan pembeli yaitu 0,393 yang lebih kecil dari angka ketidak puasan terhadap produk yaitu 0,405 . Perlu dilakukan perbaikan kualitas dari produk untuk memenuhi kepuasan dari konsumen. UMKM Succes Creative sebaiknya mengutamakan peningkatkan kualitas karakteristik produk yang diinginkan konsumen diantaranya daya tahan atau keawetan produk, model produk, bahan baku produk, kerapian pengecatan atau warna produk, kemsan produk yang baik, bentuk produk yang rapi dan menarik, dan finishing atau hasil pengerjaan produk yang rapi.
\end{abstract}

Kata Kunci: kualitas, produk, Customer, Satifaction, Index 


\section{PENDAHULUAN}

Kualitas produk menjadi salah satu perhatian yang sangat penting bagi suatu perusahaan dalam menciptakan sebuah produk. Dengan produk yang berkualitas perusahaan dapat bersaing dengan para kompetitor dalam menguasai pangsa pasar dan perusahaan mampu senantiasa mempertahankan serta meningkatkan kualitas produk yang dihasilkan guna memenuhi keinginan dari konsumen. Produk yang berkualitas menjadi kriteria utama dari konsumen dalam pemilihan produk yang ditawarkan oleh perusahaan.

Menurut Schiffman dan Kanuk (2007), kualitas produk adalah kemampuan suatu perusahaan untuk memberikan identitas atau cirri pada setiap produknya sehingga konsumen dapat mengenali produk tersebut. Dengan memperhatikan kualitas produk maka tujuan perusahaan untuk mendapatkan laba yang optimal dapat terpenuhi sekaligus dapat memenuhi tuntutan konsumen akan produk yang berkualitas dengan harga kompetitif.

Karakteristik dari produk yang dihasilkan sebuah perusahaan akan sangat mempengaruhi kepuasan konsumen dan berbagai aspek yang ada dalam perusahaan tersebut. UMKM Success Creative merupakan suatu badan usaha milik perorangan yang berjalan dari tahun 2016 hingga saat ini. Usaha yang dijalankan yaitu berbagai produk kerajinan terbuat dari berbagai limbah kayu dan barang-barang lainya yang memiliki nilai seni dan dapat diolah lagi sehingga menjadi barang yang bernilai jual. Kepuasan pelanggan akan menentukan kualitas produk yang dihasilkan oleh pihak perusahaan terhadap kinerjanya dalam menghasilkan suatu produk. Keluhan pelanggan terhadap produk kerajinan kayu yang dihasilkan oleh UMKM Succes Creative menjadi latar belakang mendasar untuk menganalisis permasalahan kualitas hasil produk yang dipasarkan, dan mengetahui kriteria produk diinginkan oleh konsumen.

Hal tersebut dilakukan agar perusahaan mampu memenuhi ekspektasi konsumen terhadap produk yang dihasilkan, maka kepuasan konsumen dapat terpenuhi. Kemudian perusahaan memiliki citra dan produk yang baik dimata konsumen, karena apa bila tidak dilakukan analisis karakteristik suatu produk yang diinginkan konsumen maka tingkat kepuasan pelanggan dikhawatirkan akan terus mengalami penurunan dan jumlah keluhan pelanggan terhadap produk yang dipasarkan akan terus meningkat.

UMKM Succes Creative belum melakukan analisis mengenai karakteristik dan model produk kerajinan yang diinginkan oleh konsumen. Sering terjadi keluhan dari konsumen tentang produk yang diterimanya, contohnya pada bulan Desember terdapat keluhan mengenai produk kerajinan yang diterima oleh konsumen dapat dilihat pada tabel berikut:

Tabel 1. Keluhan Pelanggan Pada Bulan Desember.

\begin{tabular}{|c|c|}
\hline Produk & Keluhan Pelanggan \\
\hline Jam Kayu & $\begin{array}{l}\text { 1. Mesin Jam Mati } \\
\text { 2. Jarum Jam Copot } \\
\text { 3. Cat Kurang Rapi } \\
\text { 4. Angka Pada Jam Copot } \\
\text { 5. Packing Rusak } \\
\text { 6. Mesin Jam Tidak Awet }\end{array}$ \\
\hline Kaligrafi & $\begin{array}{ll}\text { 1. } & \text { Cat Rusak } \\
\text { 2. Kemasan Rusak } \\
\text { 3. Dudukan Kaligrafi Copot } \\
\text { 4. Produk Patah Pada } \\
\text { Saat Pengiriman } \\
\text { 5. Ukuran Tidak Sesuai } \\
\text { Pesanan }\end{array}$ \\
\hline $\begin{array}{l}\text { Gantungan } \\
\text { Kunci }\end{array}$ & $\begin{array}{l}\text { 1. Ring Gantungan Kunci } \\
\text { Copot } \\
\text { 2. Pecah } \\
\text { 3. Ring Gantungan Kunci } \\
\text { Bengkok } \\
\text { 4. Kurang Rapi } \\
\text { 5. Desain Kurang Rapi }\end{array}$ \\
\hline
\end{tabular}

Sehingga UMKM Succes Creative harus mengganti produk yang tidak sesuai dengan keinginan konsumen. Seperti penelitian yang dilakukan Sembiring, dkk. (2014) yang melakukan penelitian dengan judul Pengaruh "Kualitas Produk Dan Kualitas Pelayanan Terhadap Kepuasan Pelanggan Dalam Membentuk Loyalitas Pelanggan", Wijoyo, dkk. (2014) tentang kualitas produk terhadap kepuasan konsumen, dan Devani, dkk. (2016) menganalisis pengaruh kualitas produk menggunakan metode Customer Satisfaction Index dan Potential Gain In Customer Value yang hasilnya menunjukkan adanya pengaruh antara kualitas produk dengan kepuasan 
pelanggan. Dalam penelitian ini dilakukan untuk menganalisis dan mengevaluasi produk dari segi karakteristik dan kualitas produk sesuai dengan ekspektasi pelanggan, penelitian ini dilakukan dengan mengajukan kuesioner pertanyaan tentang produk seperti apa yang diperlukan atau diinginkan oleh konsumen UMKM Succes Creative, kemudian dijadikan bahan perbaikan dalam proses produksi selanjutnya.

\section{METODE PENELITIAN}

Dalam penelitian Tugas Akhir ini dilkukan di UMKM Succes Creative desa Donorejo. Sedangkan obyek penelitian ini adalah konsumen yang membeli produk yang dihasilkan dari UMKM Succes Creative sebagai responden penelitian ini. Kuesioner digunakan sebagai alat bantu untuk memudahkan dalam pengambilan data tentang kualitas produk yang dihasilkan terhadap kepuasan konsumen UMKM Succes Creative.

Banyaknya pelanggan UMKM Succes Creative dapat menghambat survey secara keseluruhan karena keterbatasan waktu. Oleh karena itu dibutuhkan sampel yang dapat mewakili semua pelanggan UMKM Succes Creative. Cara menentukan jumlah sampel menggunakan Rumus Slovin (Sugiyono, 2007).

\section{Tahapan Penelitian}

Tahapan-tahapan yang dilakukan dalam penelitian ini akan ditunjukan pada Gambar

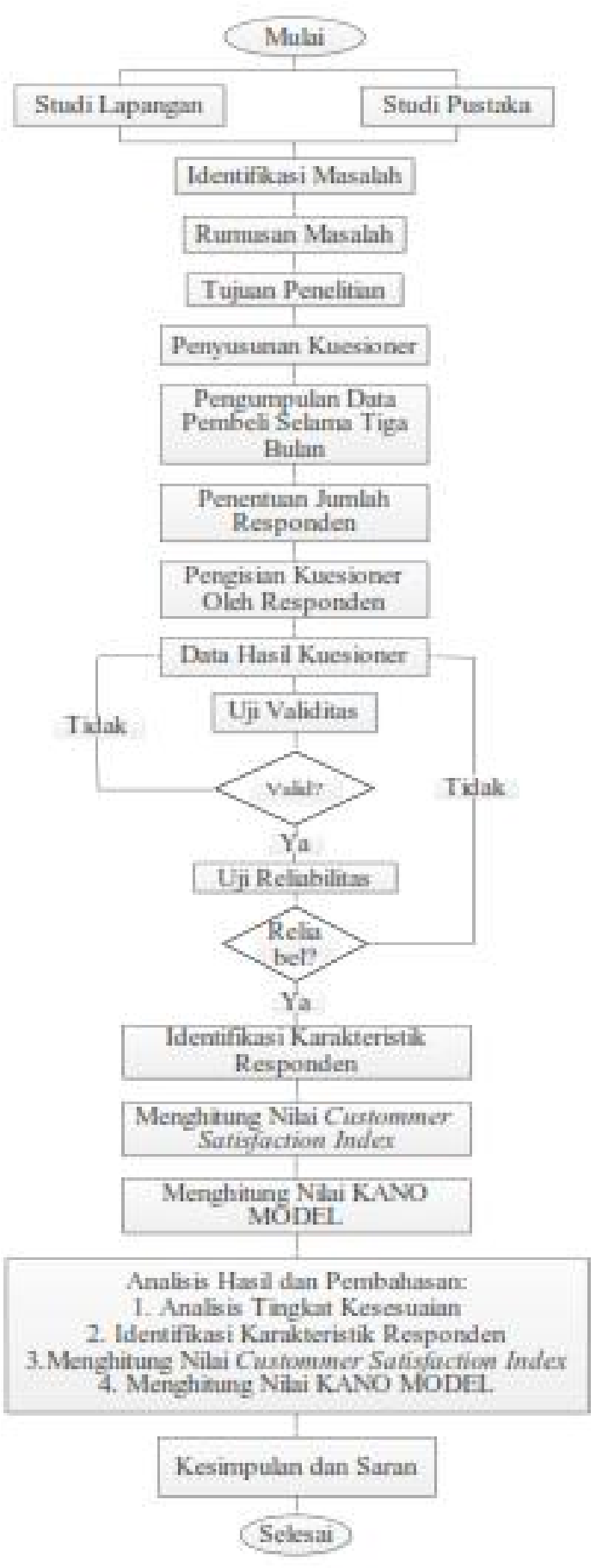

Tabel 2. Jumlah Pembeli Kerajinan Succes

Creative

\begin{tabular}{|l|c|c|c|l|}
\hline \multirow{2}{*}{ Bulan } & \multicolumn{3}{|c|}{ Kerajinan } & Jumlah \\
\cline { 2 - 4 } & $\begin{array}{c}\text { Gantungan } \\
\text { kunci }\end{array}$ & $\begin{array}{c}\text { Kaligrafi } \\
\text { Kayu }\end{array}$ & $\begin{array}{c}\text { Jam } \\
\text { Kayu }\end{array}$ & \\
\hline Desember & 73 & 184 & 121 & 378 \\
\hline Januari & 235 & 156 & 196 & 587 \\
\hline Februari & 282 & 92 & 135 & 509 \\
\hline Jumlah & 590 & 432 & 452 & \\
\hline
\end{tabular}

(Sumber: UMKM Succes Creative, 2019 
Berdasarkan Tabel 2 diatas jumlah pembelian kerajinan terbanyak pada bulan Februari dengan jumlah pada kerajinan gantungan kunci sebanyak 282 produk terjual, produk kerajinan kayu kaligrafi terbanyak pada bulan Desember 184 produk terjual, dan jam kayu pada bulan Januari 196 pembeli, dengan jumlah total terbanyak penjualan produk pada setiap bulanya yaitu 587 dari ketiga produk diatas yang. Dalam penelitian ini, penentuan jumlah responden menggunakan persamaan rumus (2.1) dengan jumlah sampel ( $N$ ) 587 demgan margin of error $20 \%$ atau 0,2 .

$$
\begin{aligned}
& n=N / N(\mathrm{~d})^{2}+1 \\
& n=\frac{587}{\left(587\left(0,2^{2}\right)+1\right)} \\
& n=\frac{587}{24,48} \\
& n=21,93
\end{aligned}
$$

Jadi jumlah responden yang digunakan untuk sampel pada penelitian ini adalah 22 responden.

\section{a. Kesioner Kualitas Produk}

Preferensi pelanggan didapatkan berdasarkan pengisian kuesioner yang dilakukan oleh responden dengan mengisi pernyataan-pernyataan yang telah disediakan berdasarkan tingkat kualitas produk yang dipasarkan kepada konsumen oleh UMKM Succes Creative. Dibawah ini merupakan hasil rekapitulasi kuesioner kualitas produk yang telah diberikan oleh pihak UMKM Succes Creative, ditunjukan pada tabel berikut.

Tabel 3. Rekapitulasi kuesioner Kualitas

Produk

\begin{tabular}{|c|c|c|c|}
\hline \multirow{2}{*}{$\begin{array}{c}\text { Kode } \\
\text { Atribut }\end{array}$} & \multicolumn{3}{|c|}{ Nama Variabel } \\
\cline { 2 - 4 } & $\begin{array}{c}\text { Tidak } \\
\text { Setuju }\end{array}$ & $\begin{array}{c}\text { Cukup } \\
\text { Setuju }\end{array}$ & Setuju \\
\hline K1 & 3 & 12 & 7 \\
\hline K2 & 1 & 12 & 9 \\
\hline K3 & 4 & 7 & 11 \\
\hline K4 & 4 & 12 & 6 \\
\hline K5 & 3 & 14 & 5 \\
\hline K6 & 3 & 12 & 7 \\
\hline K7 & 5 & 11 & 6 \\
\hline K8 & 3 & 11 & 8 \\
\hline
\end{tabular}

Tabel 4. Rekapitulasi kuesioner Kualitas Produk Gantungan Kunci

\begin{tabular}{|c|c|c|c|}
\hline \multirow{2}{*}{$\begin{array}{c}\text { Kode } \\
\text { Atribut }\end{array}$} & \multicolumn{3}{|c|}{ Nama Variabel } \\
\cline { 2 - 4 } & $\begin{array}{r}\text { Tidak } \\
\text { Setuju }\end{array}$ & $\begin{array}{c}\text { Cukup } \\
\text { Setuju }\end{array}$ & Setuju \\
\hline K1 & 4 & 14 & 4 \\
\hline K2 & 6 & 8 & 8 \\
\hline K3 & 4 & 11 & 7 \\
\hline K4 & 3 & 13 & 6 \\
\hline K5 & 5 & 7 & 10 \\
\hline
\end{tabular}

Tabel 5. Rekapitulasi kuesioner Kualitas Produk Kaligrafi

\begin{tabular}{|c|c|c|c|}
\hline \multirow{2}{*}{$\begin{array}{c}\text { Kode } \\
\text { Atribut }\end{array}$} & \multicolumn{3}{|c|}{ Nama Variabel } \\
\cline { 2 - 4 } & $\begin{array}{c}\text { Tidak } \\
\text { Setuju }\end{array}$ & $\begin{array}{c}\text { Cukup } \\
\text { Setuju }\end{array}$ & Setuju \\
\hline K1 & 6 & 7 & 9 \\
\hline K2 & 7 & 7 & 8 \\
\hline K3 & 5 & 6 & 11 \\
\hline K4 & 5 & 7 & 10 \\
\hline K5 & 4 & 9 & 9 \\
\hline K6 & 3 & 7 & 12 \\
\hline K7 & 6 & 8 & 8 \\
\hline
\end{tabular}

Keterangan:

$\mathrm{K} 1-\mathrm{K} 8=$ Kode atribut kualitas produk berdasarkan kenyataan menurut konsumen.

b. Kuesioner Tingkat Kepentingan Karakteristik Produk

Preferensi pelanggan didapatkan berdasarkan pengisian kuesioner yang dilakukan oleh responden dengan mengisi pernyataan-pernyataan yang telah disediakan berdasarkan tingkat kepentingan karakteristik produk yang diinginkan oleh responden. Preferensi konsumen tentang tingkat kepentingan karakteristik yang diinginkan konsumen, ditunjukan pada tabel berikut.

Tabel 6. Rekapitulasi Kuesioner Tingkat Kepentingan Karakteristik Produk Jam Kayu

\begin{tabular}{|c|c|c|c|}
\hline \multirow{2}{*}{$\begin{array}{c}\text { Kode } \\
\text { Atribut }\end{array}$} & \multicolumn{3}{|c|}{ Nama Variabel } \\
\cline { 2 - 4 } & $\begin{array}{c}\text { Tidak } \\
\text { Setuju }\end{array}$ & $\begin{array}{c}\text { Cukup } \\
\text { Setuju }\end{array}$ & Setuju \\
\hline TK-1 & 2 & 5 & 15 \\
\hline TK-2 & 3 & 5 & 14 \\
\hline TK-3 & 2 & 6 & 14 \\
\hline TK-4 & 1 & 4 & 17 \\
\hline TK-5 & 1 & 7 & 16 \\
\hline TK-6 & 3 & 8 & 11 \\
\hline TK-7 & 0 & 10 & 12 \\
\hline TK-8 & 2 & 7 & 13 \\
\hline
\end{tabular}


Tabel 7. Rekapitulasi Kuesioner Tingkat Kepentingan Karakteristik Produk Gantungan Kunci

\begin{tabular}{|c|c|c|c|}
\hline \multirow{2}{*}{$\begin{array}{c}\text { Kode } \\
\text { Atribut }\end{array}$} & \multicolumn{3}{|c|}{ Nama Variabel } \\
\cline { 2 - 4 } & $\begin{array}{c}\text { Tidak } \\
\text { Setuju }\end{array}$ & $\begin{array}{c}\text { Cukup } \\
\text { Setuju }\end{array}$ & Setuju \\
\hline TK-1 & 2 & 7 & 13 \\
\hline TK-2 & 3 & 6 & 13 \\
\hline TK-3 & 4 & 4 & 14 \\
\hline TK-4 & 2 & 3 & 17 \\
\hline TK-5 & 1 & 7 & 14 \\
\hline
\end{tabular}

Tabel 8. Rekapitulasi Kuesioner Tingkat Kepentingan Karakteristik Produk Kaligrafi

\begin{tabular}{|c|c|c|c|}
\hline \multirow{2}{*}{$\begin{array}{c}\text { Kode } \\
\text { Atribut }\end{array}$} & \multicolumn{3}{|c|}{ Nama Variabel } \\
\cline { 2 - 4 } & $\begin{array}{c}\text { Tidak } \\
\text { Setuju }\end{array}$ & $\begin{array}{c}\text { Cukup } \\
\text { Setuju }\end{array}$ & Setuju \\
\hline TK-1 & 4 & 9 & 9 \\
\hline TK-2 & 5 & 6 & 11 \\
\hline TK-3 & 1 & 10 & 11 \\
\hline TK-4 & 1 & 5 & 16 \\
\hline TK-5 & 2 & 7 & 13 \\
\hline TK-6 & 0 & 12 & 10 \\
\hline TK-7 & 0 & 11 & 11 \\
\hline
\end{tabular}

Keterangan:

$\mathrm{K} 1-\mathrm{K} 8$ = Kode atribut kualitas produk berdasarkan tingkat kepentingan karakteristik produk.

\section{UJI VALIDITAS}

Data preferensi konsumen yang telah diisikan berdasarkan kuesioner tentang kualitas produk yang dihasilkan UMKM Succes Creative kemudian diuji validitasnya menggunakan software SPSS 16.0 for Windows. Hal ini dilakukan agar data atribut tingkat kualitas produk yang didapat dari responden benar-benar valid.

1. Uji Validitas Hasil Kuesioner Kenyataan

Berikut merupakan hasil keterangan uji validitas dari kuesioner yang diberikan terhadap pelanggan UMKM Succes Creative ditunjuk kan pada tabel berikut apakah valid atau tidak.

a. Menentukan nilai r-tabel

$$
\text { (df) } \begin{aligned}
& =\mathrm{n}-2 \\
& =22-2 \\
& =20
\end{aligned}
$$

maka nilai r-tabel pada tingkat kepercayaan sebesar $5 \%$, baris ke 20 didapatkan nilai r-tabel sebesar 0,4044 . b. Menentukan nilai r-hitung

$$
\begin{aligned}
& \mathrm{K} 1=\frac{(N(\Sigma \mathrm{xy})-(\Sigma \mathrm{x})(\Sigma \mathrm{y}))}{\sqrt{N \Sigma x^{2}(\Sigma \mathrm{x})^{2} \sqrt{\left(N \Sigma y^{2}-(\Sigma \mathrm{y})^{2}\right.}}} \\
& =\frac{(22(872)-(48)(388))}{\sqrt{(22)(9)(48)^{2}} \sqrt{(22)(4761)-(338)^{2}}} \\
& =0,6282 \text { (dan seterusnya) }
\end{aligned}
$$

Tabel 9. Hasil Uji Validitas Kuesioner Kualitas Jam Kayu Berdasarkan Kenyataan

\begin{tabular}{|c|r|r|c|}
\hline $\begin{array}{c}\text { Nomor } \\
\text { Atribut }\end{array}$ & r-hitung & r-tabel & Keterangan \\
\hline K1 & 0,6282 & 0.4044 & VALID \\
\hline K2 & 0,4772 & 0.4044 & VALID \\
\hline K3 & 0,5581 & 0.4044 & VALID \\
\hline K4 & 0,4554 & 0.4044 & VALID \\
\hline K5 & 0,5302 & 0.4044 & VALID \\
\hline K6 & 0,4554 & 0.4044 & VALID \\
\hline K7 & 0,7154 & 0.4044 & VALID \\
\hline K8 & 0,4503 & 0.4044 & VALID \\
\hline
\end{tabular}

Dari rekapitulasi data berdasarkan tabel diatas didapatkan bahwa semua atribut atau pernyataan yang terdapat pada kesioner untuk mengukur tingkat kualitas produk kerajinan jam kayu UMKM Succes Creative dinyatakan valid. Karena hasil uji validitas lebih besar dari nilai tabel $r$ yaitu sebesar 0,4044.

Tabel 10. Hasil Uji Validitas Kuesioner Kualitas Gantungan Kunci Berdasarkan Kenyataan

\begin{tabular}{|c|r|r|c|}
\hline $\begin{array}{c}\text { Nomor } \\
\text { Atribut }\end{array}$ & r-hitung & r-tabel & Keterangan \\
\hline K1 & 0,5035 & 0.4044 & VALID \\
\hline K2 & 0,6725 & 0.4044 & VALID \\
\hline K3 & 0,4116 & 0.4044 & VALID \\
\hline K4 & 0,4570 & 0.4044 & VALID \\
\hline K5 & 0,6781 & 0.4044 & VALID \\
\hline
\end{tabular}

Dari rekapitulasi data berdasarkan tabel diatas didapatkan bahwa semua atribut atau pernyataan yang terdapat pada kesioner untuk mengukur tingkat kualitas produk gantungan kunci kayu UMKM Succes Creative dinyatakan valid. Karena hasil uji validitas lebih besar dari nilai tabel $r$ yaitu sebesar 0,4044 
Tabel 11. Hasil Uji Validitas Kuesioner Kualitas Kaligrafi Berdasarkan Kenyataan

\begin{tabular}{|c|c|c|c|}
\hline $\begin{array}{c}\text { Nomor } \\
\text { Atribut }\end{array}$ & r-hitung & r-tabel & Keterangan \\
\hline K1 & 0,4338 & 0.4044 & VALID \\
\hline K2 & 0,6170 & 0.4044 & VALID \\
\hline K3 & 0,4642 & 0.4044 & VALID \\
\hline K4 & 0,7544 & 0.4044 & VALID \\
\hline K5 & 0,4668 & 0.4044 & VALID \\
\hline K6 & 0,4372 & 0.4044 & VALID \\
\hline K7 & 0,5347 & 0.4044 & VALID \\
\hline
\end{tabular}

Dari rekapitulasi data berdasarkan tabel diatas didapatkan bahwa semua atribut atau pernyataan yang terdapat pada kesioner untuk mengukur tingkat kualitas produk kerajinan kaligrafi UMKM Succes Creative dinyatakan valid. Karena hasil uji validitas lebih besar dari nilai tabel $r$ yaitu sebesar 0,4044.

\section{Uji Validitas Hasil Kuesioner Tingkat} Kepentingan

Setelah dilakukan uji validitas kenyataan, selanjutnya akan dilakukan uji validitas harapan. Hal tersebut dilakukan agar data atribut tingkat kualitas produk benar-benar valid. Berikut hasil keterangan uji validitas harapan ditunjukan pada tabel berikut.

a. Menentukan nilai r-hitung

$$
\begin{aligned}
& \text { TK-1 }=\frac{(N(\Sigma x y)-(\Sigma x)(\Sigma y))}{\sqrt{N \Sigma x^{2}(\Sigma x)^{2} \sqrt{\left(N \Sigma y^{2}-(\Sigma y)^{2}\right.}}} \\
& =\frac{(22(1182)-(57)(448))}{\sqrt{(22)(4)(57)^{2}} \sqrt{(22)(1182)-(448)^{2}}} \\
& =0,50678 \text { (dan seterusnya) }
\end{aligned}
$$

Tabel 12. Hasil Uji Validitas Hasil Kuesioner Tingkat Kepentingan Kualitas Karakteristik Produk Jam Kayu

\begin{tabular}{|c|c|c|c|}
\hline $\begin{array}{c}\text { Nomor } \\
\text { Atribut }\end{array}$ & r-hitung & r-tabel & Keterangan \\
\hline TK-1 & 0,50678 & 0.4044 & VALID \\
\hline TK-2 & 0,49322 & 0.4044 & VALID \\
\hline TK-3 & 0,58267 & 0.4044 & VALID \\
\hline TK-4 & 0,46649 & 0.4044 & VALID \\
\hline TK-5 & 0,67938 & 0.4044 & VALID \\
\hline TK-6 & 0,65708 & 0.4044 & VALID \\
\hline TK-7 & 0,48688 & 0.4044 & VALID \\
\hline TK-8 & 0,7786 & 0.4044 & VALID \\
\hline
\end{tabular}

Dapat dilihat dari rekapitulasi pada tabel diatas semua atribut atau pernyataan yang terdapat pada kuesioner tingkat kepentingan kualitas karakteristik jam kayu dinyatakan valid karena nilai uji validias diatas nilai tabel $r$ yaitu sebesar 0,4044.

Tabel 13. Hasil Uji Validitas Hasil Kuesioner Tingkat Kepentingan Kualitas Karakteristik Produk Gantungan Kunci

\begin{tabular}{|c|c|c|c|}
\hline $\begin{array}{c}\text { Nomor } \\
\text { Atribut }\end{array}$ & r-hitung & r-tabel & Keterangan \\
\hline TK-1 & 0,45661 & 0.4044 & VALID \\
\hline TK-2 & 0,47769 & 0.4044 & VALID \\
\hline TK-3 & 0,58028 & 0.4044 & VALID \\
\hline TK-4 & 0,47063 & 0.4044 & VALID \\
\hline TK-5 & 0,46005 & 0.4044 & VALID \\
\hline
\end{tabular}

Dapat dilihat dari rekapitulasi pada tabel diatas semua atribut atau pernyataan yang terdapat pada kuesioner tingkat kepentingan kualitas karakteristik gantungan kunci dinyatakan valid karena nilai uji validias diatas nilai tabel $r$ yaitu sebesar 0,4044 .

Tabel 14. Hasil Uji Validitas Hasil Kuesioner Tingkat Kepentingan Kualitas Karakteristik Kaligrafi

\begin{tabular}{|c|c|c|c|}
\hline $\begin{array}{c}\text { Nomor } \\
\text { Atribut }\end{array}$ & r-hitung & r-tabel & Keterangan \\
\hline TK-1 & 0,45427 & 0.4044 & VALID \\
\hline TK-2 & 0,41058 & 0.4044 & VALID \\
\hline TK-3 & 0,5227 & 0.4044 & VALID \\
\hline TK-4 & 0,45918 & 0.4044 & VALID \\
\hline TK-5 & 0,64432 & 0.4044 & VALID \\
\hline TK-6 & 0,4086 & 0.4044 & VALID \\
\hline TK-7 & 0,80648 & 0.4044 & VALID \\
\hline
\end{tabular}

Dapat dilihat dari rekapitulasi pada tabel diatas semua atribut atau pernyataan yang terdapat pada kuesioner tingkat kepentingan kualitas karakteristik kaligrafi dinyatakan valid karena nilai uji validias diatas nilai tabel $r$ yaitu sebesar 0,4044.

\section{UJI RELIABILITAS}

Tingkat reliabilitas suatu pengukur dapat digolongkan menjadi lima, berikut penggolongan tingkat reliabilitas ditunjukan pada tabel berikut.

Tabel 15. Tingkat Reliabilitas

\begin{tabular}{|c|c|}
\hline Nilai & Keterangan \\
\hline $0-0,200$ & Kurang Reliabel \\
\hline $0,201-0,400$ & Agak Reliabel \\
\hline $0,401-0,600$ & Cukup Reliabel \\
\hline $0,601-0,800$ & Reliabel \\
\hline $0,801-1$ & Sangat Reliabel \\
\hline
\end{tabular}


1. Berikut hasil uji reliabilitas menggunakan metode alpha cronbach hasil kuesioner berdasarkan kenyataan karakteristik produk menurut konsumen.

Tabel 16. Hasil Pengujian Reliabilitas Hasil

Kuesioner Kenyataan Produk Jam Kayu

\begin{tabular}{|c|c|c|}
\hline \multicolumn{3}{|c|}{ Reliability Statistics } \\
\hline & $\begin{array}{c}\text { Cronbach's } \\
\text { Alpha Based } \\
\text { on } \\
\begin{array}{c}\text { Cronbach's } \\
\text { Alpha }\end{array}\end{array}$ & \\
\hline $\begin{array}{c}\text { Standardized } \\
\text { Items }\end{array}$ & N of Items \\
\hline, 645 &, 643 & 8 \\
\hline
\end{tabular}

Dari tabel diatas diketahui nilai uji reliabilitas kenyataan cronbach alpha sebesar 0,645 . Dari hasil tersebut maka dapat disimpulkan hasil pengujian ini dapat dikatakan sangat reliabel.

Tabel 17. Hasil Pengujian Reliabilitas Hasil Kuesioner Kenyataan Produk Gantungan Kunci

\begin{tabular}{|r|r|r|}
\hline \multicolumn{3}{|c|}{ Reliability Statistics } \\
\hline $\begin{array}{c}\text { Cronbach's } \\
\text { Alpha Based } \\
\text { on } \\
\text { Alphach's }\end{array}$ & $\begin{array}{c}\text { Standardized } \\
\text { Items }\end{array}$ & N of Items \\
\hline, 427 &, 413 & 5 \\
\hline
\end{tabular}

Dari tabel diatas diketahui nilai uji reliabilitas kenyataan cronbach alpha sebesar 0,427 . Dari hasil tersebut maka dapat disimpulkan hasil pengujian ini dapat dikatakan cukup reliabel.

Tabel 18. Hasil Pengujian Reliabilitas Hasil Kuesioner Kenyataan Produk Kaligrafi

\begin{tabular}{|c|c|c|}
\hline \multicolumn{3}{|c|}{ Reliability Statistics } \\
\hline $\begin{array}{l}\text { Cronbach's } \\
\text { Alpha }\end{array}$ & $\begin{array}{c}\text { Cronbach's } \\
\text { Alpha Based } \\
\text { on } \\
\text { Standardized } \\
\text { Items }\end{array}$ & $\mathrm{N}$ of Items \\
\hline, 575 &, 573 & 7 \\
\hline
\end{tabular}
reliabilitas kenyataan cronbach alpha sebesar 0,575. Dari hasil tersebut maka dapat disimpulkan hasil pengujian ini dapat dikatakan cukup reliabel.
2. Berikut hasil uji reliabilitas menggunakan metode alpha cronbach hasil kuesioner tingkat kepentingan karakteristik produk.

Tabel 19. Hasil Pengujian Reliabilitas Hasil Kuesioner Tingkat Kepentingan Karakteristik Produk Jam Kayu

\begin{tabular}{|r|c|r|}
\hline \multicolumn{3}{|c|}{ Reliability Statistics } \\
\hline $\begin{array}{c}\text { Cronbach's } \\
\text { Alpha }\end{array}$ & $\begin{array}{c}\text { Cronbach's } \\
\text { Alpha Based } \\
\text { on } \\
\text { Ontandardized } \\
\text { Items }\end{array}$ & N of Items \\
\hline, 720 &, 722 & 8 \\
\hline
\end{tabular}

Dari tabel diatas dapat dilihat nilai uji reliabilitas tingkat kepentingan karakteristik produk jam kayu cronbach's alpha sebesar 0,720. Dengan ini dapat disimpulkan, kuesioner yang digunakan pada penelitian ini dakatakan Sangat Reliabel.

Tabel 20. Hasil Pengujian Reliabilitas Hasil Kuesioner Tingkat Kepentingan Karakteristik Produk Gantungan Kunci

\begin{tabular}{|r|c|c|}
\hline \multicolumn{3}{|c|}{ Reliability Statistics } \\
\hline $\begin{array}{c}\text { Cronbach's } \\
\text { Alpha Based } \\
\text { on } \\
\text { Alphach's }\end{array}$ & $\begin{array}{c}\text { Standardized } \\
\text { Items }\end{array}$ & N of Items \\
\hline, 210 &, 213 & \\
\hline
\end{tabular}

Dari tabel diatas dapat dilihat nilai uji reliabilitas tingkat kepentingan karakteristik gantungan kunci cronbach's alpha sebesar 0,210 . Dengan ini dapat disimpulkan, kuesioner yang digunakan pada penelitian ini dakatakan agak reliabel.

Tabel 21. Hasil Pengujian Reliabilitas Hasil Kuesioner Tingkat Kepentingan Karakteristik Produk Kaligrafi

\begin{tabular}{|c|c|c|}
\hline \multicolumn{3}{|c|}{ Reliability Statistics } \\
\hline & $\begin{array}{l}\text { Cronbach's } \\
\text { Alpha } \\
\text { Based on }\end{array}$ & \\
\hline $\begin{array}{l}\text { Cronbach's } \\
\text { Alpha }\end{array}$ & $\begin{array}{l}\text { Standardized } \\
\text { Items }\end{array}$ & $\mathrm{N}$ of Items \\
\hline .531 & $57 \varepsilon$ & \\
\hline
\end{tabular}

Dari tabel diatas dapat dilihat nilai uji reliabilitas tingkat kepentingan karakteristik kaligrafi cronbach's alpha sebesar 0,531. Dengan ini dapat disimpulkan, kuesioner yang 
digunakan pada penelitian ini dakatakan cukup reliabel.

\section{Penilaian Service Performance}

Penilaian service performance digunakan untuk mengukur tingkat kesesuaian masingmasing atribut kualitas pada kondisi kenyataan yang ada di UMKM Succes Creative dengan kualitas produk yang diharapkan oleh pelanggan. Tingkat kesesuaian diukur dengan membagi rata-rata nilai atribut kualitas pada tingkat kinerja dengan tingkat kepentingan atau harapan kemudian dikalikan 100\%.

Tingkat Kesesuaian =

$$
\frac{\text { rata-rata tingkat kenyataan }}{\text { rata-rata tingkat kepentingan }} \times 100 \%
$$

Berikut ini adalah contoh perhitungan tingkat kesesuaian pada atribut kualitas nomor 1 .

$$
\begin{aligned}
& \text { Tingkat Kesesuaian }=\frac{2,18}{2,59} \times 100 \% \\
& =84,21 \% \text { (dan seterusnya) }
\end{aligned}
$$

Tabel 22. Hasil Perhitungan Tingkat Kesesuaian Variabel Kualitas Produk Jam Kayu

\begin{tabular}{|c|c|c|c|}
\hline $\begin{array}{c}\text { Nomor } \\
\text { Atribut }\end{array}$ & $\begin{array}{c}\text { Rata-rata } \\
\text { Kenyataan }\end{array}$ & $\begin{array}{c}\text { Rata-rata } \\
\text { tingkat } \\
\text { Kepentingan }\end{array}$ & $\begin{array}{c}\text { Tingkat } \\
\text { kesesuaian }\end{array}$ \\
\hline 1 & 2,18 & 2,59 & $84,21 \%$ \\
\hline 2 & 2,36 & 2,50 & $94,55 \%$ \\
\hline 3 & 2,32 & 2,55 & $91,07 \%$ \\
\hline 4 & 2,18 & 2,73 & $80,00 \%$ \\
\hline 5 & 2,09 & 2,59 & $80,70 \%$ \\
\hline 6 & 2,18 & 2,36 & $92,31 \%$ \\
\hline 7 & 2,09 & 2,55 & $89,09 \%$ \\
\hline 8 & 2,23 & 2,50 & $84,21 \%$ \\
\hline
\end{tabular}

Dari hasil pengolahan data tingkat kesesuaian yang terdapat pada tabel diatas mengenai atribut kualitas produk kerajinan jam kayu yang dipasarkan UMKM Succes Creative diketahui hasil tingkat kesesuaian dengan nilai prosentase antara $80 \%-94,55 \%$, maka dapat disimpulkan bahwa kesesuaian harapan konsumen hampir terpenuhi.
Tabel 23. Hasil Perhitungan Tingkat

Kesesuaian Variabel Kualitas Produk Gantungan Kunci

\begin{tabular}{|c|c|c|c|}
\hline $\begin{array}{c}\text { Nomor } \\
\text { Atribut }\end{array}$ & $\begin{array}{c}\text { Rata-rata } \\
\text { Kenyataan }\end{array}$ & $\begin{array}{c}\text { Rata-rata } \\
\text { tingkat } \\
\text { Kepentingan }\end{array}$ & $\begin{array}{c}\text { Tingkat } \\
\text { kesesuaian }\end{array}$ \\
\hline 1 & 2,00 & 2,50 & $80,00 \%$ \\
\hline 2 & 2,09 & 2,45 & $85,19 \%$ \\
\hline 3 & 2,14 & 2,45 & $87,19 \%$ \\
\hline 4 & 2,14 & 2,31 & $92,54 \%$ \\
\hline 5 & 2,14 & 2,40 & $89,00 \%$ \\
\hline
\end{tabular}

Dari hasil pengolahan data tingkat kesesuaian yang terdapat pada tabel diatas mengenai atribut kualitas produk kerajinan gantungan kunci yang dipasarkan UMKM Succes Creative diketahui hasil tingkat kesesuaian dengan nilai prosentase antara 80\%-92,54\%, maka dapat disimpulkan bahwa kesesuaian harapan konsumen hampir terpenuhi.

Tabel 24. Hasil Perhitungan Tingkat Variabel Kualitas Produk Kaligrafi

\begin{tabular}{|c|c|c|c|}
\hline $\begin{array}{c}\text { Nomor } \\
\text { Atribut }\end{array}$ & $\begin{array}{c}\text { Rata-rata } \\
\text { Kenyataan }\end{array}$ & $\begin{array}{c}\text { Rata-rata } \\
\text { tingkat } \\
\text { Kepentingan }\end{array}$ & $\begin{array}{c}\text { Tingkat } \\
\text { kesesuaian }\end{array}$ \\
\hline 1 & 2,05 & 2,23 & $91,84 \%$ \\
\hline 2 & 1,93 & 2,16 & $89,42 \%$ \\
\hline 3 & 1,93 & 2,16 & $88,95 \%$ \\
\hline 4 & 1,92 & 2,12 & $90,53 \%$ \\
\hline 5 & 1,86 & 2,08 & $89,81 \%$ \\
\hline 6 & 1,86 & 2,03 & $92,08 \%$ \\
\hline 7 & 1,86 & 2,03 & $92,02 \%$ \\
\hline
\end{tabular}

Dari hasil pengolahan data tingkat kesesuaian yang terdapat pada tabel diatas mengenai atribut kualitas produk kerajinan kaligrafi yang dipasarkan UMKM Succes Creative diketahui hasil tingkat kesesuaian dengan nilai prosentase antara 88,95\%$92,08 \%$, maka dapat disimpulkan bahwa kesesuaian harapan konsumen hampir terpenuhi.

\section{Pengukuran Customer Satisfaction Index}

Pengukuran CSI digunakan untuk mengetahui tingkat kepuasan pembeli secara menyeluruh dengan melihat tingkat kepentingan dari atribut-atribut kualitas. Untuk pengukuran CSI dapat dilakukan melalui tahapan-tahapan berikut ini: 
a. Menentukan Mean Importance Score (MIS) dan Mean Satisfaction Score (MSS).

Nilai MIS dan MSS didapatkan dari ratarata nilai atribut masing-masing kualitas. MSI untuk tingkat kepentingan atau harapan, sedangkan MSS untuk tingkat kinerja. Perhitungan MIS pada atribut kualitas nomor satu mengunakan rumus persamaan.

$$
\begin{aligned}
& \text { MIS }=\frac{\Sigma \frac{n}{i}=1 \mathrm{Yi}}{n} \\
& \text { MIS }=\frac{48}{22} \\
& \text { MIS }=2,18(\text { dan seterusnya })
\end{aligned}
$$

Perhitungan MSS pada atribut kualitas nomor satu menggunakan rumus persamaan

$$
\begin{gathered}
\text { MSS }=\frac{\Sigma=\frac{n}{i} \mathbf{1} \mathbf{X} \mathbf{i}}{n} \\
\text { MSS }=\frac{57}{22} \\
\text { MSS }=2,59(\text { dan }
\end{gathered}
$$

seterusnya)

b. Membuat Weight Factors (WF) per atribut.

Bobot ini merupakan presentase nilai MIS per atribut terhadap total MIS. Perhitungan WF pada atribut kualitas nomor satu menggunakan rumus persamaan

$$
\begin{aligned}
& \mathrm{WF}=\frac{M I S \boldsymbol{i}}{\Sigma \frac{p}{i}=1 \boldsymbol{M I S} \boldsymbol{i}} \\
& \mathrm{WF}=\frac{2,18}{17,63} \\
& \mathrm{WF}=0,124 \text { (dan seterusnya) }
\end{aligned}
$$

c. Membuat Weigt Score (WSi) pada tiap atribut.

Bobot ini merupakan perkalian antara WF dengan MSS. Perhitungan WSi pada atribut kualitas nomor satu menggunakan rumus persamaan

$$
\begin{aligned}
& \mathbf{W S} \mathbf{i}=\mathbf{W F} \mathbf{X} \text { MSS } \\
& W S i=0,124 \times 2,59 \\
& W S i=0,320 \text { (dan seterusnya) }
\end{aligned}
$$

d. Menghitung Customer Satisfaction Index (CSI)

Dengan cara Weight Total (WT) dibagi skala maksimum yang digunakan kemudian dikalikan $100 \%$.

Tabel 25. Rekapitulasi Hasil Perhitungan Customer Satisfaction Index (CSI) Variabel Kualitas Produk Jam Kayu

\begin{tabular}{|c|c|c|c|c|}
\hline $\begin{array}{c}\text { No. Atrib } \\
\text { ut Kualit } \\
\text { as }\end{array}$ & $\begin{array}{c}\text { Mean } \\
\text { Impor } \\
\text { tance } \\
\text { Score } \\
\text { (MIS) }\end{array}$ & $\begin{array}{c}\text { Weight } \\
\text { Factors } \\
\text { (WF) } \\
\text { (MIS/T } \\
\text { otal } \\
\text { MIS) }\end{array}$ & $\begin{array}{c}\text { Mean } \\
\text { Satisf } \\
\text { action } \\
\text { Score } \\
\text { (MSS) }\end{array}$ & $\begin{array}{c}\text { Weigt } \\
\text { Score } \\
\text { (WSi) } \\
\text { (WFX } \\
\text { MSS) }\end{array}$ \\
\hline 1 & 2,18 & 0,124 & 2,59 & 0,320 \\
\hline 2 & 2,36 & 0,134 & 2,50 & 0,335 \\
\hline 3 & 2,32 & 0,132 & 2,55 & 0,336 \\
\hline 4 & 2,18 & 0,124 & 2,73 & 0,338 \\
\hline 5 & 2,09 & 0,119 & 2,59 & 0,307 \\
\hline 6 & 2,18 & 0,124 & 2,36 & 0,292 \\
\hline 7 & 2,09 & 0,119 & 2,55 & 0,302 \\
\hline 8 & 2,23 & 0,126 & 2,50 & 0,316 \\
\hline Total & $\mathbf{1 7 , 6 3}$ & $\mathbf{1}$ & $\mathbf{2 0 , 3 7}$ & $\mathbf{2 , 5 4 5}$ \\
\hline & & & &
\end{tabular}

Berdasarkan rekapitulasi hasil perhitugan pada tabel didapatkan hasil nilai total Weight Score sebesar 2,545. Langkah selanjutnya adalah menentukan nilai Customer Satisfaction Index dengan rumus persamaan.

$$
\begin{aligned}
& \mathrm{CSI}=\frac{\boldsymbol{\Sigma} \frac{p}{\boldsymbol{i}}=\mathbf{1} \boldsymbol{W S} \boldsymbol{i}}{\boldsymbol{H} \boldsymbol{S}} \boldsymbol{x} \mathbf{1 0 0} \% \\
& \mathrm{CSI}=\frac{2,545}{5} \times 100 \% \\
& \mathrm{CSI}=50,90 \%
\end{aligned}
$$

Dari perhitungan Customer Satisfaction Index diatas didapatkan prosentase hasil sebesar $50,90 \%$, dari hasil yang didapatkan maka dapat dikatakan tingkat kualitas produk yang dihasilkan UMKM Succes Creative terhadap konsumen tergolong dalam kriteria Very Poor, yang artinya kualitas dari produk kerajinan jam kayu yang dipasarkan masih sangat kurang baik. 
Tabel 26. Rekapitulasi Hasil Perhitungan Customer Satisfaction Index (CSI) Variabel Kualitas Produk Gantungan Kunci

\begin{tabular}{|c|c|c|c|c|}
\hline $\begin{array}{c}\text { No. Atrib } \\
\text { ut Kualit } \\
\text { as }\end{array}$ & $\begin{array}{c}\text { Mean } \\
\text { Impor } \\
\text { tance } \\
\text { Score } \\
\text { (MIS) }\end{array}$ & $\begin{array}{c}\text { Weight } \\
\text { Factors } \\
\text { (WF) } \\
\text { (MIS/T } \\
\text { otal } \\
\text { MIS) }\end{array}$ & $\begin{array}{c}\text { Mean } \\
\text { Satisf } \\
\text { action } \\
\text { Score } \\
\text { (MSS) }\end{array}$ & $\begin{array}{c}\text { Weigt } \\
\text { Score } \\
\text { (WSi) } \\
\text { (WF } x \\
\text { MSS) }\end{array}$ \\
\hline 1 & 2,00 & 0,190 & 2,50 & 0,476 \\
\hline 2 & 2,09 & 0,199 & 2,45 & 0,487 \\
\hline 3 & 2,14 & 0,204 & 2,45 & 0,499 \\
\hline 4 & 2,14 & 0,204 & 2,31 & 0,470 \\
\hline 5 & 2,14 & 0,204 & 2,40 & 0,489 \\
\hline Total & $\mathbf{1 0 , 5 1}$ & $\mathbf{1}$ & $\mathbf{1 2 , 1 1}$ & $\mathbf{2 , 4 2 1}$ \\
\hline
\end{tabular}

Berdasarkan rekapitulasi hasil perhitungan pada tabel didapatkan hasil nilai total Weight Score sebesar 2,421. Langkah selanjutnya adalah menentukan nilai Customer Satisfaction Index dengan rumus persamaan.

$$
\begin{aligned}
& \mathrm{CSI}=\frac{\boldsymbol{\Sigma}_{\boldsymbol{i}}=\mathbf{1} \boldsymbol{W S} \boldsymbol{i}}{\boldsymbol{H} \boldsymbol{S}} \boldsymbol{x} \mathbf{1 0 0} \% \\
& \mathrm{CSI}=\frac{2,421}{5} \times 100 \% \\
& \mathrm{CSI}=48,42 \%
\end{aligned}
$$

Dari perhitungan Customer Satisfaction Index diatas didapatkan prosentase hasil sebesar $48,42 \%$, dari hasil yang didapatkan maka dapat dikatakan tingkat kualitas produk yang dihasilkan UMKM Succes Creative terhadap konsumen tergolong dalam kriteria Very Poor, yang artinya kualitas dari produk kerajinan gantungan kunci yang dipasarkan masih sangat kurang baik.

Tabel 27. Rekapitulasi Hasil Perhitungan Customer Satisfaction Index (CSI) Variabel Kualitas Produk Kaligrafi

\begin{tabular}{|c|c|c|c|c|}
\hline $\begin{array}{c}\text { No. Atrib } \\
\text { ut Kualit } \\
\text { as }\end{array}$ & $\begin{array}{c}\text { Mean } \\
\text { Impor } \\
\text { tance } \\
\text { Score } \\
\text { (MIS) }\end{array}$ & $\begin{array}{c}\text { Weight } \\
\text { Factors } \\
\text { (WF) } \\
\text { (MIS/T } \\
\text { otal } \\
\text { MIS) }\end{array}$ & $\begin{array}{c}\text { Mean } \\
\text { Satisf } \\
\text { action } \\
\text { Score } \\
\text { (MSS) }\end{array}$ & $\begin{array}{c}\text { Weigt } \\
\text { Score } \\
\text { (WSi) } \\
\text { (WFX } \\
\text { MSS) }\end{array}$ \\
\hline 1 & 2,05 & 0,153 & 2,23 & 0,341 \\
\hline 2 & 1,93 & 0,144 & 2,16 & 0,311 \\
\hline 3 & 1,93 & 0,144 & 2,16 & 0,311 \\
\hline 4 & 1,92 & 0,143 & 2,12 & 0,304 \\
\hline 5 & 1,86 & 0,139 & 2,08 & 0,289 \\
\hline 6 & 1,86 & 0,139 & 2,03 & 0,282 \\
\hline 7 & 1,86 & 0,139 & 2,03 & 0,282 \\
\hline Total & $\mathbf{1 3 , 4 1}$ & $\mathbf{1}$ & $\mathbf{1 4 , 8 1 0}$ & $\mathbf{2 , 1 1 8}$ \\
\hline
\end{tabular}

Berdasarkan rekapitulasi hasil perhitungan pada tabel didapatkan hasil nilai total Weight Score sebesar 2,118. Langkah selanjutnya adalah menentukan nilai Customer Satisfaction Index dengan rumus persamaan

$$
\begin{aligned}
& \text { CSI }=\frac{\boldsymbol{\Sigma} \frac{p}{i}=1}{\boldsymbol{H} \boldsymbol{W} \boldsymbol{S} \boldsymbol{i}} \boldsymbol{x} \mathbf{1 0 0} \% \\
& \mathrm{CSI}=\frac{2,118}{5} \times 100 \% \\
& \mathrm{CSI}=42,35 \%
\end{aligned}
$$

Dari perhitungan Customer Satisfaction Index diatas didapatkan prosentase hasil sebesar $42,35 \%$, dari hasil yang didapatkan maka dapat dikatakan tingkat kualitas produk yang dihasilkan UMKM Succes Creative terhadap konsumen tergolong dalam kriteria Very Poor, yang artinya kualitas dari produk kerajinan kaligrafi yang dipasarkan masih sangat kurang baik. Berdasarkan hasil perhitungan dan penggolongan kriteria dari masing-masing variabel karakteristik produk yang dipasarkan, maka UMKM Succes Creative sangat perlu melakukan perbaikan kualitas dari produk yang dihasilkan atau dipasarkan dan juga dilakukanya pengecekan kualitas produk sebelum dipasarkan. Karena dari hasil perhitungan didapatkan prosentase kualitas produk menurut konsumen berada dalam kreteria yang rendah.

\section{Kano Model}

Untuk mengetahui apakah karakteristik variabel kualitas dan harga produk dari masing-masing atribut kuesioner mengenai produk kerajinan UMKM Succes Creative sangat berpengaruh terhadap kepuasan pelanggan atau konsumen., maka dilakukan penilaian menggunakan metode Kano Model. Berikut hasil kuesioner yang telah diisi oleh responden dalam penelitian ini: 
Tabel 28. Hasil Kuesioner Variabel Kualitas Produk Jam Kayu

\begin{tabular}{|c|c|c|c|c|c|c|}
\hline \multirow{2}{*}{ No. } & \multirow{2}{*}{ Pernyataan } & \multicolumn{5}{|c|}{ Kategori Kano } \\
\hline & & A & $\mathbf{M}$ & I & $\mathbf{O}$ & $\mathbf{R}$ \\
\hline K1 & $\begin{array}{l}\text { Kerajinan jam } \\
\text { kayu } \\
\text { yang dihasilkan } \\
\text { Succes } \\
\text { Creative } \\
\text { memiliki daya } \\
\text { tahan yang } \\
\text { baik }\end{array}$ & 13 & 6 & 3 & 0 & 0 \\
\hline $\mathrm{K} 2$ & $\begin{array}{l}\text { Menggunakan } \\
\text { meesin } \\
\text { jam yang } \\
\text { bagus dan } \\
\text { awet }\end{array}$ & 12 & 4 & 3 & 2 & 1 \\
\hline K3 & $\begin{array}{l}\text { Succes Creative } \\
\text { menggunakan } \\
\text { bahan baku } \\
\text { yang bagus }\end{array}$ & 4 & 9 & 7 & 2 & 0 \\
\hline K4 & $\begin{array}{l}\text { Pengecatan atau } \\
\text { warna produk } \\
\text { sangat rapi }\end{array}$ & 5 & 12 & 3 & 1 & 1 \\
\hline K5 & $\begin{array}{l}\text { Komponen jam } \\
\text { kayu } \\
\text { berfungsi } \\
\text { dengan baik }\end{array}$ & 10 & 5 & 6 & 1 & 0 \\
\hline K6 & $\begin{array}{l}\text { Produk kerajinan } \\
\text { dikemas } \\
\text { dengan baik } \\
\text { dan aman }\end{array}$ & 9 & 7 & 2 & 1 & 2 \\
\hline K7 & $\begin{array}{l}\text { Memiliki bentuk } \\
\text { produk yang } \\
\text { sangat rapi } \\
\text { dan menarik }\end{array}$ & 7 & 10 & 2 & 3 & 0 \\
\hline K8 & $\begin{array}{l}\text { Finishing atau } \\
\text { hasil } \\
\text { pengerjaan } \\
\text { produk } \\
\text { sangat rapi }\end{array}$ & 11 & 8 & 3 & 0 & 0 \\
\hline
\end{tabular}

Tabel 29. Hasil Kuesioner Variabel Kualitas Produk Gantungan Kunci

\begin{tabular}{|c|l|c|c|c|c|c|}
\hline & \multicolumn{1}{|c|}{ Pernyataan } & \multicolumn{5}{|c|}{ Kategori Kano } \\
\cline { 3 - 8 } No. & \multicolumn{1}{|c|}{ Perny } & M & I & O & R \\
\hline K1 & $\begin{array}{l}\text { Bahan baku dan } \\
\text { ring gantungan } \\
\text { kunci yang } \\
\text { digunakan bagus }\end{array}$ & 4 & 13 & 3 & 1 & 1 \\
\hline K2 & $\begin{array}{l}\text { Semua komponen } \\
\text { trpasang dengan } \\
\text { baik }\end{array}$ & 10 & 6 & 5 & 1 & 0 \\
\hline K3 & $\begin{array}{l}\text { Desain/model } \\
\text { gantungan kunci } \\
\text { bagus }\end{array}$ & 9 & 7 & 3 & 1 & 2 \\
\hline K4 & Finishing rapi & 6 & 10 & 3 & 3 & 0 \\
\hline K5 & $\begin{array}{l}\text { Produk dikemas } \\
\text { dengan baik }\end{array}$ & 9 & 10 & 3 & 0 & 0 \\
\hline
\end{tabular}

Tabel 30. Hasil Kuesioner Variabel Kualitas Produk Kaligrafi

\begin{tabular}{|c|c|c|c|c|c|c|}
\hline \multirow{2}{*}{ No. } & \multirow{2}{*}{ Pernyataan } & \multicolumn{5}{|c|}{ Kategori Kano } \\
\hline & & $\mathbf{A}$ & $\mathbf{M}$ & I & 0 & $\mathbf{R}$ \\
\hline $\mathrm{K} 1$ & $\begin{array}{l}\text { Kerajinan } \\
\text { kaligrafi } \\
\text { kayu yang } \\
\text { dihasilkan } \\
\text { Succes Creative } \\
\text { memiliki daya } \\
\text { tahan yang baik } \\
\text { (awet) }\end{array}$ & 11 & 7 & 3 & 1 & 0 \\
\hline $\mathrm{K} 2$ & $\begin{array}{l}\text { Menggunakan } \\
\text { bahan } \\
\text { baku yang bagus }\end{array}$ & 10 & 6 & 3 & 2 & 1 \\
\hline K3 & $\begin{array}{l}\text { Hasil pengerjaan } \\
\text { sangat rapi }\end{array}$ & 3 & 11 & 7 & 1 & 0 \\
\hline $\mathrm{K} 4$ & $\begin{array}{l}\text { Ukuran dan } \\
\text { model } \\
\text { kaligrafi dapat } \\
\text { disesuaikan } \\
\text { dengan } \\
\text { pemesanan }\end{array}$ & 6 & 11 & 3 & 1 & 1 \\
\hline K5 & $\begin{array}{l}\text { Bentuknya } \\
\text { sangat } \\
\text { detail dan bagus }\end{array}$ & 9 & 7 & 6 & 0 & 0 \\
\hline $\mathrm{K} 6$ & $\begin{array}{l}\text { Cat rapi dan } \\
\text { tidak } \\
\text { mudah } \\
\text { mengelupas }\end{array}$ & 9 & 8 & 3 & 1 & 1 \\
\hline K7 & $\begin{array}{l}\text { Dikemas dengan } \\
\text { baik }\end{array}$ & 5 & 12 & 3 & 1 & 0 \\
\hline
\end{tabular}

\section{Uji Validitas Hasil Kuesioner Metode Kano Model}

Berikut merupakan hasil keterangan uji validitas dari kuesioner yang diberikan terhadap pelanggan UMKM Succes Creative ditunjukkan pada tabel berikut apakah valid atau tidak dengan nilai r-tabel 0,4044

Tabel 31. Hasil Uji Validitas Kuesioner Kualitas Jam Kayu Berdasarkan Kenyataan

\begin{tabular}{|c|c|c|c|}
\hline $\begin{array}{c}\text { Nomor } \\
\text { Atribut }\end{array}$ & r-hitung & r-tabel & Keterangan \\
\hline K1 & 0,442483 & 0.4044 & VALID \\
\hline K2 & 0,524459 & 0.4044 & VALID \\
\hline K3 & 0,421477 & 0.4044 & VALID \\
\hline K4 & 0,435981 & 0.4044 & VALID \\
\hline K5 & 0,456793 & 0.4044 & VALID \\
\hline K6 & 0,445464 & 0.4044 & VALID \\
\hline K7 & 0,674388 & 0.4044 & VALID \\
\hline K8 & 0,429167 & 0.4044 & VALID \\
\hline
\end{tabular}


Tabel 32. Hasil Uji Validitas Kuesioner Kualitas Gantungan Kunci Berdasarkan Kenyataan

\begin{tabular}{|c|c|c|c|}
\hline $\begin{array}{c}\text { Nomor } \\
\text { Atribut }\end{array}$ & r-hitung & r-tabel & Keterangan \\
\hline K1 & 0,432911 & 0.4044 & VALID \\
\hline K2 & 0,460813 & 0.4044 & VALID \\
\hline K3 & 0,549635 & 0.4044 & VALID \\
\hline K4 & 0,68535 & 0.4044 & VALID \\
\hline K5 & 0,42935 & 0.4044 & VALID \\
\hline
\end{tabular}

Tabel 33. Hasil Uji Validitas Kuesioner Kualitas Kaligrafi Berdasarkan Kenyataan

\begin{tabular}{|c|c|c|c|}
\hline $\begin{array}{c}\text { Nomor } \\
\text { Atribut }\end{array}$ & r-hitung & r-tabel & Keterangan \\
\hline K1 & 0,478232 & 0.4044 & VALID \\
\hline K2 & 0,527616 & 0.4044 & VALID \\
\hline K3 & 0,458484 & 0.4044 & VALID \\
\hline K4 & 0,438445 & 0.4044 & VALID \\
\hline K5 & 0,407974 & 0.4044 & VALID \\
\hline K6 & 0,564158 & 0.4044 & VALID \\
\hline K7 & 0,682556 & 0.4044 & VALID \\
\hline
\end{tabular}

Dari hasil perhitungan masing-masing karakteristi produk jam kayu, gantungan kunci, dan kaligrafi dikatakan valid, karena nilai $r$ hutung lebih besar dari pada nilai r-tabel.

\section{Uji Reliabilitas Hasil Kuesioner Metode Kano Model}

Berikut hasil uji reliabilitas menggunakan metode alpha cronbach hasil kuesioner kano model.

Tabel 34. Hasil Uji Reliabilitas Kuesioner Kano Model Kualitas Produk Jam Kayu

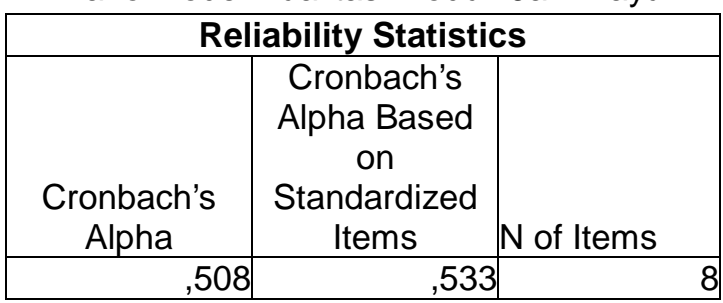

Dari tabel diatas dapat dilihat nilai uji reliabilitas tingkat kepentingan karakteristik jam kayu cronbach's alpha sebesar 0,508. Dengan ini dapat disimpulkan, kuesioner kano model yang digunakan pada penelitian ini dakatakan cukup reliabel.
Tabel 35. Hasil Uji Reliabilitas Kuesioner Kano Model Kualitas Produk Gantungan Kunci

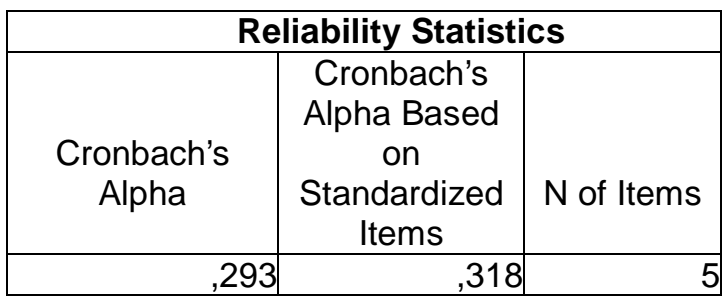

Dari tabel diatas dapat dilihat nilai uji reliabilitas tingkat kepentingan karakteristik gantungan kunci cronbach's alpha sebesar 0,293. Dengan ini dapat disimpulkan, kuesioner kano model yang digunakan pada penelitian ini dakatakan agak reliabel.

Tabel 36. Hasil Uji Reliabilitas Kuesioner Kano Model Kualitas Produk Kaligrafi

\begin{tabular}{|r|r|r|}
\hline \multicolumn{3}{|c|}{ Reliability Statistics } \\
\hline $\begin{array}{c}\text { Cronbach's } \\
\text { Alpha }\end{array}$ & $\begin{array}{c}\text { Clpha Based } \\
\text { on } \\
\text { on } \\
\text { Standardized } \\
\text { Items }\end{array}$ & N of Items \\
\hline, 502 &, 532 & 7 \\
\hline
\end{tabular}

Dari tabel diatas dapat dilihat nilai uji reliabilitas tingkat kepentingan karakteristik kaligrafi cronbach's alpha sebesar 0,502. Dengan ini dapat disimpulkan, kuesioner kano model yang digunakan pada penelitian ini dakatakan cukup reliabel.

\section{Kategori Hasil Kuesioner Variabel Kualitas Produk Menurut Responden}

Setelah kuesioner disebarkan kemudian diperoleh data katagori hasil kuesioner menggunakan metode Kano Model, dapat dilihat pada tabel berikut ini ini: 
Tabel 37. Kategori Hasil Kuesioner Variabel Kualitas Produk Jam Kayu

\begin{tabular}{|c|l|c|}
\hline No. & \multicolumn{1}{|c|}{ Pernyataan } & $\begin{array}{c}\text { Kategori } \\
\text { Kano }\end{array}$ \\
\hline K1 & $\begin{array}{l}\text { Kerajinan jam kayu yang } \\
\text { dihasilkan Succes Creative } \\
\text { memiliki daya tahan yang } \\
\text { baik }\end{array}$ & $\mathrm{A}$ \\
\hline $\mathrm{K} 2$ & $\begin{array}{l}\text { Menggunakan meesin jam } \\
\text { yang bagus dan awet }\end{array}$ & $\mathrm{A}$ \\
\hline $\mathrm{K} 3$ & $\begin{array}{l}\text { Succes Creative } \\
\text { menggunakan bahan } \\
\text { baku yang bagus }\end{array}$ & $\mathrm{M}$ \\
\hline $\mathrm{K} 4$ & $\begin{array}{l}\text { Pengecatan atau warna } \\
\text { produk sangat rapi }\end{array}$ & $\mathrm{M}$ \\
\hline $\mathrm{K} 5$ & $\begin{array}{l}\text { Komponen jam kayu } \\
\text { berfungsi dengan baik }\end{array}$ & $\mathrm{A}$ \\
\hline $\mathrm{K} 6$ & $\begin{array}{l}\text { Produk kerajinan dikemas } \\
\text { dengan baik dan aman }\end{array}$ & $\mathrm{A}$ \\
\hline $\mathrm{K} 7$ & $\begin{array}{l}\text { Memiliki bentuk produk } \\
\text { yang sangat rapi dan } \\
\text { menarik }\end{array}$ & $\mathrm{M}$ \\
\hline $\mathrm{K} 8$ & $\begin{array}{l}\text { Finishing atau hasil } \\
\text { pengerjaan produk sangat } \\
\text { rapi }\end{array}$ & $\mathrm{A}$ \\
\hline
\end{tabular}

Dari hasil responden yang terdapat pada tabel diatas kemudian dilakukan perhitungan untuk mengetahui kategori Kano yang paling berpengaruh terhadap karakteristik kualitas produk kerajinan dari UMKM Succes Creative. Perhitungan dapat dilihat dibawah ini.

Jumlah Responden Kano $=$ Jumlah keseluruhan masing-masing kategori Kano Jumlah pertanyaan tiap dimensi

$$
\begin{aligned}
& \text { A. Kategori (I) } \\
& =\frac{0}{22} \\
& \text { B. Kategori (A) } \\
& =\frac{5}{8} \\
& =0,62 \\
& \text { C. Kategori (M) } \\
& =\frac{3}{8} \\
& =0,37 \\
& \text { D. Kategori }(\mathrm{O}) \\
& \begin{array}{l}
=\frac{0}{8} \\
=0
\end{array}
\end{aligned}
$$

Dari hasil perhitungan kuesioner berdasarkan pilihan responden pada perhitungan variabel kualitas produk jam kayu dengan metode Kano Model diatas dapat diketahui jumlah nilai terbanyak pilihan respoden adalan $\mathrm{A}$ (Atractive) dengan hasil perhitungan sebesar 0,62. Yang artinya apabila kinerja dan kualitas ditingkatkan maka kepuasan pelanggan akan ikut meningkat.

Tabel 38. Kategoti Hasil Kuesioner Variabel Kualitas Gantungan Kunci

\begin{tabular}{|c|l|c|}
\hline No. & \multicolumn{1}{|c|}{ Pernyataan } & $\begin{array}{c}\text { Kategori } \\
\text { Kano }\end{array}$ \\
\hline K1 & $\begin{array}{l}\text { Bahan baku dan ring } \\
\text { gantungan kunci yang } \\
\text { digunakan bagus }\end{array}$ & $\mathrm{M}$ \\
\hline K2 & $\begin{array}{l}\text { Semua komponen terpasang } \\
\text { dengan baik }\end{array}$ & $\mathrm{A}$ \\
\hline K3 & $\begin{array}{l}\text { Desain/model gantungan } \\
\text { kunci } \\
\text { bagus }\end{array}$ & $\mathrm{A}$ \\
\hline K4 & \begin{tabular}{l} 
Finishing rapi \\
\hline K5
\end{tabular} & $\begin{array}{l}\text { Produk dikemas dengan } \\
\text { baik }\end{array}$ \\
\hline
\end{tabular}

Dari hasil responden yang terdapat pada tabel diatas kemudian dilakukan perhitungan untuk mengetahui kategori Kano yang paling berpengaruh terhadap karakteristik kualitas produk kerajinan dari UMKM Succes Creative. Perhitungan dapat dilihat dibawah ini.

Jumlah Responden Kano $=$ Jumlah keseluruhan masing-masing kategori Kano Jumlah pertanyaan tiap dimensi
A. Kategori (I)
$=\frac{0}{5}$
$=0$
B. Kategori (A)
$\begin{aligned} & =\frac{3}{5} \\ & =0,6\end{aligned}$
C. Kategori (M) $=\frac{3}{5}$
$=0,6$
D. Kategori $(\mathrm{O})$ $=\frac{0}{5}$
$=0$

Dari hasil perhitungan kuesioner berdasarkan pilihan responden pada perhitungan variabel kualitas produk gantungan kunci dengan metode Kano Model 
diatas dapat diketahui jumlah nilai terbanyak pilihan respoden adalan $\mathrm{M}$ (Must-Be) dengan hasil perhitungan sebesar 0,6. Yang artinya pelanggan akan merasa puas apabila kinerja dari atribut semakin baik.

Tabel 39. Kategoti Hasil Kuesioner Variabel Kualitas Produk Kaligrafi

\begin{tabular}{|l|l|c|}
\hline No. & \multicolumn{1}{|c|}{ Pernyataan } & $\begin{array}{c}\text { Kategori } \\
\text { Kano }\end{array}$ \\
\hline K1 & $\begin{array}{l}\text { Kerajinan kaligrafi kayu } \\
\text { yang dihasilkan Succes } \\
\text { Creative memiliki daya tahan } \\
\text { yang baik (awet) }\end{array}$ & A \\
\hline K2 & $\begin{array}{l}\text { Menggunakan bahan baku } \\
\text { yang bagus }\end{array}$ & $\mathrm{A}$ \\
\hline K3 & $\begin{array}{l}\text { Hasil pengerjaan sangat rapi } \\
\text { K4 }\end{array}$ & $\begin{array}{l}\text { Ukuran dan model kaligrafi } \\
\text { dapat disesuaikan dengan } \\
\text { pemesanan }\end{array}$ \\
\hline K5 & $\begin{array}{l}\text { Bentuknya sangat detail dan } \\
\text { bagus }\end{array}$ & $\mathrm{M}$ \\
\hline K6 & $\begin{array}{l}\text { Cat rapi dan tidak mudah } \\
\text { mengelupas }\end{array}$ & $\mathrm{A}$ \\
\hline K7 & Dikemas dengan baik & $\mathrm{M}$ \\
\hline
\end{tabular}

Dari hasil responden yang terdapat pada tabel diatas kemudian dilakukan perhitungan untuk mengetahui kategori Kano yang paling berpengaruh terhadap karakteristik kualitas produk kerajinan dari UMKM Succes Creative. Perhitungan dapat dilihat dibawah ini.

Jumlah Responden Kano $=$ Jumlah keseluruhan masing-masing kategori Kano Jumlah pertanyaan tiap dimensi
A. Kategori (I)$$
\begin{aligned}
& =\frac{0}{7} \\
& =0
\end{aligned}
$$
B. Kategori (A)

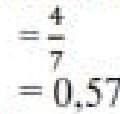
C. Kategori (M)

$$
=\frac{3}{7}
$$$$
=0,42
$$
D. Kategori $(\mathrm{O})$

$$
=\frac{0}{7}
$$$$
=0
$$

Dari hasil perhitungan kuesioner berdasarkan pilihan responden pada perhitungan variabel kualitas produk kaligrafi dengan metode Kano Model diatas dapat diketahui jumlah nilai terbanyak pilihan respoden adalan $\mathrm{A}$ (Atractive) dengan hasil perhitungan sebesar 0,57. Yang artinya kepuasan pelanggan akan mengikuti kualitas produk yang dihasilkan, untuk itu kualitas harus semakin meningkat supaya kepuasan pelanggan juga semakin meningkat.

\section{Menghitung Kano Model}

Untuk mengetahui tingkat kepuasan pelanggan terhadap kualitas produk yang dihasilkan UMKM Succes Creative Desa Donorejo, maka dilakukan perhitungan kano sebagai berikut:

1. Menghitung tingkat kepuasan konsumen berdasarkan hasil penilaian pada variaabel kuesioner kualitas produk jam kayu menggunakan persamaan :

Kepuasan

$$
\begin{aligned}
& =\frac{(A+O)}{(A+O+M+l)} . \\
& =\frac{(11+1)}{(11+0+8+1)} . \\
& =0,571(\text { dan seterusnya) } \\
& =\frac{(O+M)}{(O+M+I+R)} \\
& =\frac{(1+8)}{(1+8+1+1)} . \\
& =0,818(\text { dan seterusnya })
\end{aligned}
$$

Tidak puas

Dengan persamaan diatas maka didapatkan hasil kepuasan dan tidak puas berdasarkan penilaian konsumen dari variabel kualitas produk jam kayu dapat dilihat pada tabel dibawah ini. 
Tabel 40. Kepuasan Dan Tidak Puas Variabel Kerajinan Jam Kayu

\begin{tabular}{|c|c|c|c|}
\hline Kode & Pernyataan & PUAS & $\begin{array}{l}\text { TIDAK } \\
\text { PUAS }\end{array}$ \\
\hline K1 & $\begin{array}{l}\text { Kerajinan jam } \\
\text { kayu yang } \\
\text { dihasilkan } \\
\text { Succes } \\
\text { Creative } \\
\text { memiliki } \\
\text { daya tahan } \\
\text { yang baik }\end{array}$ & 0,5714 & 0,8182 \\
\hline K2 & $\begin{array}{l}\text { Menggunakan } \\
\text { meesin jam } \\
\text { yang bagus dan } \\
\text { awet }\end{array}$ & 0,7143 & 0,5556 \\
\hline K3 & $\begin{array}{l}\text { Succes } \\
\text { Creative } \\
\text { menggunakan } \\
\text { bahan baku } \\
\text { yang bagus }\end{array}$ & 0,1364 & 0,6667 \\
\hline K4 & $\begin{array}{l}\text { Pengecatan } \\
\text { atau warna } \\
\text { produk sangat } \\
\text { rapi }\end{array}$ & 0,2857 & 0,7647 \\
\hline K5 & $\begin{array}{l}\text { Komponen } \\
\text { jam kayu } \\
\text { berfungsi } \\
\text { dengan baik }\end{array}$ & 0,5455 & 0,3636 \\
\hline K6 & $\begin{array}{l}\text { Produk } \\
\text { kerajinan } \\
\text { dikemas dengan } \\
\text { baik dan aman }\end{array}$ & 0,4762 & 0,6667 \\
\hline K7 & $\begin{array}{l}\text { Memiliki } \\
\text { bentuk produk } \\
\text { yang sangat } \\
\text { rapi dan } \\
\text { menarik }\end{array}$ & 0,3636 & 0,9412 \\
\hline K8 & $\begin{array}{l}\text { Finishing atau } \\
\text { hasil pengerjaan } \\
\text { produk sangat } \\
\text { rapi }\end{array}$ & 0,5455 & 1 \\
\hline
\end{tabular}

Dari hasil perhitungan yang terdapat pada tabel ditas dapat diketahui nilai rata-rata kepuasan sebesar 0,4548 sedangkan ratarata ketidak puasan sebesar 0,7221 . Dari hasil tersebut diketahui pada variabel kuesioner kualitas produk jam kayu bahwa konsumen merasa belum puas terhadap kualitas dan harga produk yang diberikan oleh UMKM Succes Creative.

\section{ANALISIS HASIL DAN PEMBAHASAN}

a. Analisis Tingkat Kesesuaian

- Analisis Service Performance

Dari hasil perhitungan Service Performance didapatkan hasil penilaian pada masing-masing atribut kualitas produk kerajinan jam kayu didapatkan hasil tingkat kesesuaian dengan nilai prosentase antara $80 \%-94,55 \%$, kerajinan gantungan kunci didapatkan hasil tingkat kesesuaian dengan nilai prosentase antara $80 \%-92,54 \%$,dan produk kerajinan kaligrafi yang dipasarkan UMKM Succes Creative didapatkan hasil tingkat kesesuaian dengan nilai prosentase antara 88,95\%$92,08 \%$, maka dapat diketahui tingkat kesesuaian dari karakteristik masing-masing produk menurut konsumen.

- Analisis Customer Satisfaction Index (CSI)

Dalam perhitungan menggunakan metode Customer Satisfaction Index (CSI) tentang kualitas produk yang dihasilkan UMKM Succes Creative didapatkan nilai prosentase kepuasan pembeli sebagai berikut.

Tabel 41. Prosentase Kualitas

\begin{tabular}{|c|c|c|}
\hline $\begin{array}{c}\text { Produk } \\
\text { Kerajinan }\end{array}$ & Prosentase & Kategori \\
\hline Jam Kayu & $50,90 \%$ & VeryPoor \\
\hline $\begin{array}{c}\text { Gantungan } \\
\text { Kunci }\end{array}$ & $38,2 \%$ & Very Poor \\
\hline Kaligrafi & $42,35 \%$ & Very Poor \\
\hline
\end{tabular}

Dari hasil perhitungan masing-masing atribut kualitas produk didapatkan hasil sesuai pada tabel diatas, dapat dikatakan bahwa kualitas produk yang dipasarkan oleh UMKM Succes Creative menurut konsumen masih sangat kurang atau belum memenuhi keteria dari keinginan konsumen karena hasil perhitungan menunjukkan nilai kualitas produk sangat rendah, sehingga sangat perlu dilakukanya peningkatan kualitas dari masingmasing produk yang dihasilkan atau dipasarkan oleh perusahaan.

- Analisis Kano Model

Dari hasil pengolahan data menggunakan metode Kano diketahui bahwa pembeli produk kerajinan UMKM Succes Creative merasa belum puas terhadap produk yang dihasilkan dari UMKM Succes Creative karena hasil perhitungan ketidak puasan lebih besar dari pada nilai kepuasan. 
Tabel 42. Nilai Kepuasan Konsumen Terhadap Produk

\begin{tabular}{|c|c|c|}
\hline Produk & Puas & $\begin{array}{c}\text { Tidak } \\
\text { Puas }\end{array}$ \\
\hline Jam Kayu & 0,4548 & 0,7221 \\
\hline $\begin{array}{c}\text { Gantungan } \\
\text { Kunci }\end{array}$ & 0,5018 & 0,7457 \\
\hline Kaligrafi & 0,1966 & 0,2219 \\
\hline
\end{tabular}

Sumber: Olah Data, 2019)

Dari hasil nilai rata-rata nilai kepuasan dan ketidak puasan konsumen diketahui bahwa tingkat kepuasan lebih rendah dari tingkat ketidak puasan, maka perusahaan harus melakukan perbaikan kualitas produk, karena sangat berpengaruh terhadap kepuasan konsumen dari UMKM Succes Creative.

\section{SIMPULAN}

Berdasarkan analisis hasil dan pembahasan, maka kesimpulan dari penelitian ini adalah hasil perhitungan Custommer Satisfaction Index pada UMKM Succes Creative didapatkan nilai tingkat kualitas produk jam kayu sebesar $65,7 \%$, gantungan kunci sebesar $38,2 \%$, kaligrafi sebesar $41,23 \%$ dimana prosentase ketiga produk tersebut berada pada kreteria Poor (rendah) yang artinya tingkat kualitas dari ketiga produk tersebut sangat rendah dan belum memenuhi kepuasan konsumen.

Oleh karena itu sangat perlu dilakukan peningkatan kualitas dari masing-masing produk yang dipasarkan oleh UMKM Succes Creative, sehingga keinginan konsumen dapat terpenuhi dan produk kerajinan yang dipasarkan semakin berkualitas. Pada perhitungan Kano Model juga didapatkan hasil rata-rata nilai ketidak puasan pembeli lebih besar yaitu pada produk jam kayu 0,4548 dengan nilai ketidak puasan 0,7221 , gantungan kunci nilai kepuasan sebesar 0,5018 sedangkan nilai ketidak puasan 0,7457 , produk kaligrafi dengan nilai kepuasa 0,1966 sedangkan ketidak puasan sebesar 0,2219 yang artinya tanggapan konsumen terhadap kualitas dari karakteristik produk yang diharapkan konsumen belum terpenuhi atau tidak puas.

\section{Saran}

Dilihat dari hasil pembahasan dan kesimpulan, disarankan pihak UMKM Succes Creative meningkatkan service performancenya agar loyalitas pelanggan semakin tinggi. Hal tersebut dapat dilakukan dengan cara memperbaiki tingkat kualitas karakteristik produk yang menurut pembeli masih kurang, mengutamakan meningkatkan kualitas karakteristik produk yang diinginkan konsumen diantaranya daya tahan atau keawetan produk, model produk, bahan baku produk, kerapian pengecatan atau warna produk, kemasan produk yang baik, bentuk produk yang rapi dan menarik, dan finishing atau hasil pengerjaan produk yang rapi. Kemudian perbaikan kualitas harus dilakukan terus menerus dan juga dilakukan pengecekan kualitas produk sebelum produk kerajinan tersebut dipasarkan, karena apabila semakin tinggi nilai kepuasan konsumen maka akan diikuti dengan pemilihan konsumen dalam membeli kerajinan di UMKM Succes Creative juga akan semakin tinggi. UMKM Succes Creative perlu melakukan penelitian atau analisis menggunakan metode Kano Model dan Custommer Satisfaction Index secara berkala sehingga dapat mengetahui tingkat kualitas produk di mata konsumen dan dapat mengetahui karakteristik keinginan konsumen terhadap produk yang dihasilkan, sehingga kepuasan dari konsumen dapat terpenuhi dan UMKM Succes Creative semakin berkembang.

\section{DAFTAR PUSTAKA}

Anggraini. L. D., Panji. D., dan Dita. M. I. (2016). Analisis Persepsi Konsumen Menggunakan Metode Importance Performance Analysis dan Customer Satifaction Index. Bandung. Jurnal Industri. Vol. 4, No. 2. PP 74-81.

Anggraeni. P. A., Kumadji. S., dan Sunarti. (2016). Pengaruh Kualitas Produk Terhadap Kepuasan Dan Loyalitas Pelanggan. Pasuruan. Jurnal Administrasi Bisnis. Vol. 37, No. 1. PP 171-177.

Devani. V., dan Rizko. R. A. (2016). Analisis Kepuasan Pelanggan dengan Menggunakan Metode Customer Satisfaction Index (CSI) Dan Potential Gain In Customer Value 
(PGCV). Yogyakarta. Jurnal Rekayasa Dan Manajemen Sistem Informasi, Vol. 2, No. 2. PP 24-29.

Dharmayanti. D. (2006). Analisis Dampak Service Performance dan Kepuasan Sebagai Moderating Variable Terhadap Loyalitas Nasabah, Jurnal Manajemen Pemasaran. PP 35-43.

Wirajaya. G. W., Wrisiati. L. P., dan Sadyasmara. C. A. (2016). Analisis Kepuasan Konsuen Terhadap Kualitas Produk Di Bali Tinggi Spa menggunakan metode customer satisfaction, dan Importance Performance Analysis. Bali. Jurnal Rekayasa Dan Manajemen Agroindustri. Vol. 4, No. 4. PP 59-69.

Ginting, R. Dan Matondang. (2013). Analisa Kepuasan Pelanggan Dengan Pendekatan Model Kano Serta Aplikasi QUALITY FUNCITON DEPLOYMENT (QFD) Untuk Meningkatkan Mutu Pelayanan Jasa Perbankan. Jurnal Teknik Industri FT USU. Vol. 1, No. 2, PP: 1-7.

Handriati. A. A., Sunaryo., dan Vebri. N. H. (2015). Analisa Kepuasan Pelayanan Publik Terhadap Kepuasan Konsumen Dengan Menggunakan Metode Servperf-IPA-CSI. Yogyakarta. Jurnal Teknologi Informasi. Vol. 21, No. 4. PP 178-190.

Hidayati. S. N., dan Prasetyo. A. P. (2015). Analisis Kualitas Pelayanan e-KTP Menggunakan Metode Customer Satifaction Index, Metode Service Quality, dan Importance Performance Analysis. Yogyakarta. Jurnal Maskipreneur. Vol. 5, No 1. PP 117-133.

Indrayani, K. dan Nofirza. (2011). Aplikasi Metode Kano Dalam Analisis Indikator Kualitas Pelayanan Di Rumah Sakit Arifin Ahmad Pekanbaru. Jurnal Sains, Teknologi dan Industri. Vol. 9, No. 1, PP 1-8.

Maulia. E. R., Matodang. A. R., dan Ginting. R. (2013). Analisis Kepuasan Pelanggan Dengan Pendekatan Model Kano Serta Aplikasi Quality Function Deployment (Qfd) Untuk Meningkatkan Mutu Pelayanan Jasa
Perbankan. e-Jurnal Teknik Industri FT USU. Vol. 1, No. 2. PP 1-7

Kurnia. M., Hartiati. A., dan Setiawan. K. (2018) Analisis Kepuasan Konsumen Terhadap Kualitas Produk dan Layanan Dengan Metode Importance Perfomance Analysis (Studi kasus: Mie Rampok Jimbaran). Jimbaran. Jurnal Rekayasa Dan Manajeme Agroindustri. Vol. 6, No. 1. PP 4556.

Musanto. T. (2004). Faktor-Faktor Kepuasan Pelanggan dan Loyalitas Pelanggan. Jurnal Manajemen \& Kewirausahaan. Vol. 6, No. 2.

Prajogo. D. I., dan Peggy. M. (2001). "Examining competitive priorities and competitive advantage in service organisations using ImportancePerformance Analysis matrix". Jurnal Managing Service Quality Vol. 21, No. 5. PP 465-483

Sembiring. I. J., Suharyono., dan Kusumawati. A. (2014). Pengaruh Kualitas Produk Dan Kualitas Pelayanan Terhadap Kepuasan Pelanggan Dalam Membentuk Loyalitas Pelanggan. (Studi Kasus: Pelanggan McDonald's MT. Haryono, Malang). Jurnal Administrasi Bisnis (JAB). Vol. 15, No. 1. PP 1-9

Setyaningsih. I. (2013). Analisis Kualitas Rumah Sakit Terhadap Pasien Menggunakan Pendekatan Lean Servperf Dan Service Performace. (Studi Kasus: Rumah Sakit X). Jurnal Spektrum Industri. Vol. 11, No. 2. PP 117-242.

Sugiyono. (2007). Metode Penelitian Administasi. Bandung: Alvabeta.

Wibowo. A. (2009). Analisis Pengaruk Kualitas Produk Terhadap Kepuasan Pelanggan. (Studi Kasus: Perumahan Sembungharjo Permai Pengembang PT.Sindur Graha Tama). Jurnal Sains Pemasaran Indonesia. Vol. 8, No. 2. PP 173-186.

Widjoyo. S, P., Samuel. H,. dan Kurniawan. R. (2014). Pengaruh Kualitas Layanan Dan Kualitas Produk Terhadap Kepuasan Pelanggan Dan Loyalitas Konsumen. (Studi Kasus: 
Restoran Happy Garden Surabaya).

Jurnal Manajemen Pemasaran. Vol.

2, No.1. PP 1-9. 